\title{
Penentuan Sumur Pengembangan Lapangan Minyak Dengan Analisa Petrofisik dan Jari-Jari Pengurasan \\ Studi Kasus : Lapangan Hanania, Lapisan Lima, Formasi Air Benakat Cekungan Sumatra Selatan
}

\author{
Aisyah Indah Irmaya \\ Staf Pengajar Prodi Teknik Perminyakan, Fakultas Teknik, Universitas Proklamasi 45 Yogyakarta \\ Coresponding Author Email : Aisyahirmaya@gmail.com
}

\section{Abstrak}

Lapangan Hanania terletak di Sub-Cekungan Jambi yang secara regional termasuk wilayah Cekungan Sumatra Selatan. Lapisan reservoir yang diharapkan produktif adalah batupasir dari formasi Air Benakat. Cadangan L-5 berdasarkan data lapangan Hanania (1 Januari 2015) sebesar 6,416 MSTB, dengan RF sebesar 24\%. Komulatif produksi 306 MSTB dan Remaining reserve sebesar 1,303 MSTB. Metodologi yang digunakan pada penelitian ini adalah dengan melakukan pengolahan data real Lapangan Hanania sehingga diperoleh interpretasi structural, interpretasi fasies, model log fasies, pemetaan geometri dan petrofisik serta jarijari pegurasan. Hasil cut - off hidrokarbon lapisan L-5 adalah porositas 0.15 fraksi dan saturasi air 0.5 fraksi. Bagian Selatan lapisan lima lapangan Hanania mempunyai kisaran nilai net sand $30-34 \mathrm{~m}$, porositas $0.22-0.25$ fraksi, permeabilitas $50-100 \mathrm{mD}$ dan saturasi air 0.55 - 0.7 fraksi. Jari-jari pengurasan, sumur-sumur produksi bagian Selatan mempunyai kisaran jari-jari pengurasan 25 50 m dengan kisaran komulatif produksi 34 - 135 Mbbl. Lokasi sumur baru yang dapat direkomendasikan yaitu pada bagian Selatan - Barat Daya.

Kata kunci : Bubble map, analisa petrofisik, cut off

\section{Abstrack}

Hanania field is located in the Sub-Basin Jambi, which regionally placed in the region of South Sumatra Basin--one of three hydrocarbon-producing basins in Sumatra. A productive reservoir layer is expected to be in Air Benakat formation. Based on calculation per January 1, 2015, Hanania field have an L-5 reserve of 6,416 MSTB, with $24 \%$ RF. Meanwhile, the amount for cumulative production and remaining reserves are 306 MSTB and 1,303 MSTB respectively. This research used real data processing methodology to obtain structural and facies interpretations, logging facies models, geometry's map and petro-physical properties as well as drainage system radius. The calculation result of the drainage system radius, which is illustrated in the form of bubble map, will be overlaid with geometry and property reservoir map. Results of calculation and analysis using the above methods are as follows: cut - off from L-5 layer are 0.15 fractions of porosity and 0.5 fractions of water saturation, Southern part of the fifth layers in Hanania field have a sand net value ranging from 30 to 34 meters, 0.22 to 0.25 fractions of porosity, 50-100 mD of permeability and 0.55 - 0.7 fractions of water saturation. Production wells in the southern part have a range of drainage system radius from 25 to $50 \mathrm{~m}$, with 34-135 Mbbl cumulative production. The location of new wells that can be recommended are the South - Southwestern .

Keyword : Bubble map, petrophisic analysis, cut off

\section{Pendahuluan}

Studi kasus dilakukan pada lapangan Hanania yang terletak di Sub-Cekungan Jambi yang secara regional termasuk wilayah Cekungan Sumatra Selatan. Berdasarkan perhitungan cadangan lapangan Hanania (1 Januari 2015) untuk L-2 sebesar 2,206 MSTB, L-3 sebesar 1,779 MSTB, L4 sebesar 2,065 MSTB dan L-5 sebesar 6,416 MSTB. Total reserve 12,466 MSTB, dengan $R F$ sebesar 24\%. Berdasarkan data produksi lapangan Hanania, komulatif produksi untuk L-2, L-3, L-4 dan L-5 secara berurutan sebesar 499 MSTB, 347 MSTB, 460 MSTB dan 306 MSTB. Remaining reserve masing-masing lapisan sebesar $30 \mathrm{MSTB}$ (L-2), 80 MSTB (L-3), 35 MSTB (L-4) dan 1303 MSTB (L-5). Hasil perhitungan cadangan inilah yang melatar belakangi penulisan jurnal ini. Tujuan penelitian ini antara lain : menganalisa petrofisik lapangan Hanania, lapisan lima kaitannya dengan penyebaran hidrokarbon, mengetahui hubungan distribusi petrofisik dalam menentukan sumur pengembangan pada lapangan Hanania, lapisan lima (L-5) Formasi Air Benakat dan membuktikan hidrokarbon dari lapangan Hanania, lapisan lima (L-5) Formasi Air Benakat masih potensial untuk diproduksikan .

\section{Pendahuluan}

Studi kasus dilakukan pada lapangan Hanania yang terletak di Sub-Cekungan Jambi yang secara regional termasuk wilayah Cekungan Sumatra Selatan. Berdasarkan perhitungan cadangan lapangan Hanania (1 Januari 2015) untuk L-2 sebesar 2,206 MSTB, L-3 sebesar 1,779 MSTB, L4 sebesar 2,065 MSTB dan L-5 sebesar 6,416 MSTB. Total reserve 12,466 MSTB, dengan $R F$ sebesar 24\%. Berdasarkan data produksi lapangan Hanania, komulatif produksi untuk L-2, L-3, L-4 dan L-5 secara berurutan sebesar 499 MSTB, 347 MSTB, 460 MSTB dan 306 MSTB. Remaining reserve masing-masing lapisan sebesar $30 \mathrm{MSTB}$ (L-2), 80 MSTB (L-3), 35 MSTB (L-4) dan 1303 MSTB (L-5). Hasil perhitungan cadangan inilah 
Penentuan Sumur Pengembangan Lapangan Minyak Dengan Analisa Petrofisik dan Jari-Jari Pengurasan

Studi Kasus : Lapangan Hanania, Lapisan Lima, Formasi Air Benakat Cekungan Sumatra Selatan

yang melatar belakangi penulisan jurnal ini. Tujuan penelitian ini antara lain : menganalisa petrofisik lapangan Hanania, lapisan lima kaitannya dengan penyebaran hidrokarbon, mengetahui hubungan distribusi petrofisik dalam menentukan sumur pengembangan pada lapangan Hanania, lapisan lima (L-5) Formasi Air Benakat dan membuktikan hidrokarbon dari lapangan Hanania, lapisan lima (L-5) Formasi Air Benakat masih potensial untuk diproduksikan .

\subsection{Tinjauan Lapangan}

Daerah penelitian terletak pada Sub-Cekungan Jambi yang secara regional termasuk wilayah Cekungan Sumatra Selatan. Cekungan ini merupakan cekungan berumur Tersier dengan orientasi umum Utara - Selatan, disebelah Barat Daya dibatasi oleh sejumlah patahan besar dan singkapan batuan dasar berumur PraTersier disepanjang Pegunungan Bukit Barisan. Kearah Timur laut dibatasi oleh Paparan Sunda, sedangkan disebelah Selatan dan Timur dibatasi oleh Tinggian Lampung. Pegunungan Tiga Puluh membatasi cekungan ini dengan cekungan Sumatra Tengah.

Lapangan ini diketemukan pada tahun 1921 berdasar pemetaan geologi permukaan. Sampai saat ini ada 212 sumur yang sudah dibor dimana sebagian besar terletak diarea tertentu (sekarang diinterpretasikan sebagai tinggian struktur Hanania). Sebagian besar sumur tersebut dibor sampai sebelum Perang Dunia ke II.

Berdasarkan laporan terdahulu terdapat 2 buah sesar yang memotong antiklin Hanania ini. Sesar pertama, berarah NW-SE, merupakan sesar normal yang memotong bagian tepi Barat sayap antiklin dengan sisi Barat merupakan bagian yang turun. Sesar ini yang merupakan hasil dari aktifitas tektonik muda diperkirakan sangat berperan sebagai media migrasi sekunder sampai terjadinya proses pemerangkapan hidrokarbon didalam lapisan-lapisan batupasir Formasi Air Benakat. Sesar kedua, dengan skala lebih kecil dan berarah hampir W-E, juga merupakan sesar normal, terletak hampir ditengah-tengah struktur, mempunyai vertical displacement sekitar 40 meter dengan sisi Utara sebagai bagian yang turun. Laporan menyebutkan bahwa hidrokarbon yang terperangkap di struktur Hanania ini mencakup area sekitar $1,85 \mathrm{~km} \times 2,76 \mathrm{~km}=5 \mathrm{~km}^{2}$.

Batupasir Air Benakat ini dipisahkan menjadi 8 (delapan) lapisan batupasir, yaitu satuan reservoar L-2, L-3, L-4, L-5, L-6, L-7, L-8 dan L-9.

\section{III.Metodologi}

1. Persiapan data meliputi data sumur, data seismik, data reservoar dan data produksi.

2. Pengolahan data seismik sehingga diperoleh interpretasi struktur.

3. Cutting diproses untuk mengetahui struktur sedimen sehingga dapat diinterpretasi fasiesnya.

4. Data log diolah untuk picking marker, korelasi sumur serta analisa petrofisik (geometri, porositas, permeabilitas dan saturasi air).

5. Dari hasil interpretasi struktur, fasies dan petrofisik dibuat model log fasies.

6. Selanjutnya dilakukan pemetaan geometri dan property reservoar. Hasilnya divalidasi dengan data core dan data-data produksi.

7. Data reservoar dan data produksi diproses untuk mendapatkan jari-jari pengurasan. Hasil perhitungan jari-jari pengurasaan digambarkan dalam bentuk bubble map. Hasil bubble map ini akan dioverlay dengan pemetaan geometri dan property reservoir untuk pengembangan lapangan.

\section{Ketersediaan Data}

Data core

Pengukuran terhadap sampel core Lapangan Hanania (permeabilitas dan porositas) telah dilakukan oleh Lemigas.

\section{Data Seismik}

Data seismik yang digunakan adalah data seismik 2D 2 line PSTM, seperti yang terlihat pada Gambar 1.

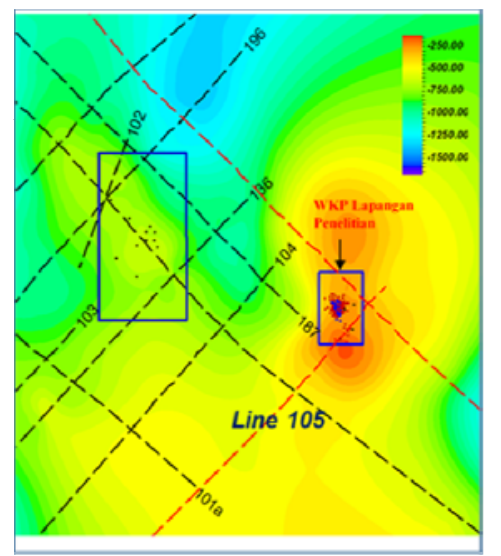

Gambar 1 Seismik line dalam penelitian 


\section{Data Cutting}

Data cutting pada penelitian ini ada pada sumur-sumur produksi baru yaitu pada $\mathrm{N}-9, \mathrm{~N}-10$, N-11, dan N-12 seperti yang terlihat pada Tabel 1.

Tabel 1. Data Cutting

\begin{tabular}{|c|c|}
\hline Sumur & Data Cutting \\
\hline N9 & $\begin{array}{l}\text { SST: } v \text { fine to fine to med } \\
\text { grain, dom fine to med grain, sb ang to } \\
\text { sb md, sli calc cmnt, tr } \\
\text { glauc, tr fosil, slicarb. }\end{array}$ \\
\hline N10 & $\begin{array}{l}\text { SST: vf-fgr, } \\
\text { sbang-sbrndd, mod-por srtd, tr pyr, tr glau. }\end{array}$ \\
\hline N11 & $\begin{array}{l}\text { SST : qrtz gr, vf- } f \mathrm{gr} \text {, sb ang-sb } \\
\text { modd, med-pr srtd, med, pr vis por, tr pyr, tr } \\
\text { glau, microlamination carb mat, tr foss } \\
\text { foram, calc cmntd. }\end{array}$ \\
\hline N12 & $\begin{array}{l}\text { SST: vfmed } \\
\text { grain, sb ang-sb mdd, mod-pr } \\
\text { srtd, pr to well srtd, qrtz grain, cal cmntd, tr } \\
\text { glau, tr pyr, tr carb matt. }\end{array}$ \\
\hline
\end{tabular}

\section{Data Log Sumur}

Data log sumur yang digunakan dalam penelitian ini terdapat pada Tabel 2.

Tabel 2.Data Log Sumur

\begin{tabular}{|c|c|c|c|c|c|}
\hline Sumur & GR & RIIOB & NFIII & KLSIS & SONIC \\
\hline H1 & $x$ & - & $\mathbf{z}$ & - & $\mathbf{I}$ \\
\hline 19 & $x$ & $x$ & $x$ & $x$ & $x$ \\
\hline $\mathrm{HB}$ & $x$ & $x$ & $\mathbf{z}$ & $x$ & $\mathbf{I}$ \\
\hline 146 & $x$ & $x$ & $\mathbf{z}$ & $x$ & $\mathbf{z}$ \\
\hline 145 & $x$ & $x$ & $x$ & - & $x$ \\
\hline $\mathbf{m}$ & $x$ & $x$ & $\mathrm{I}$ & $x$ & $\mathrm{I}$ \\
\hline $\mathbf{M}$ & $x$ & $x$ & $x$ & $x$ & $x$ \\
\hline $\mathbf{N 2}$ & $x$ & $x$ & $x$ & $x$ & $x$ \\
\hline $\mathbf{M B}$ & $x$ & $x$ & $\mathrm{z}$ & $x$ & $\mathbf{I}$ \\
\hline$M$ & $x$ & $x$ & $x$ & $x$ & $x$ \\
\hline $\mathrm{N}=7$ & $x$ & $x$ & - & $x$ & $x$ \\
\hline 14 & $x$ & $x$ & - & 县 & $x$ \\
\hline$m$ & $x$ & $x$ & - & $x$ & $x$ \\
\hline $\begin{array}{l}\mathbf{N} \\
\mathbf{H}\end{array}$ & $\begin{array}{l}x \\
x\end{array}$ & $\begin{array}{l}x \\
x\end{array}$ & $\begin{array}{l}x \\
x\end{array}$ & $\begin{array}{l}x \\
x\end{array}$ & $\begin{array}{l}x \\
x\end{array}$ \\
\hline MII & $x$ & $x$ & $x$ & $x$ & $x$ \\
\hline N12 & $x$ & $\bar{x}$ & $\bar{x}$ & $\bar{x}$ & $\bar{x}$ \\
\hline
\end{tabular}

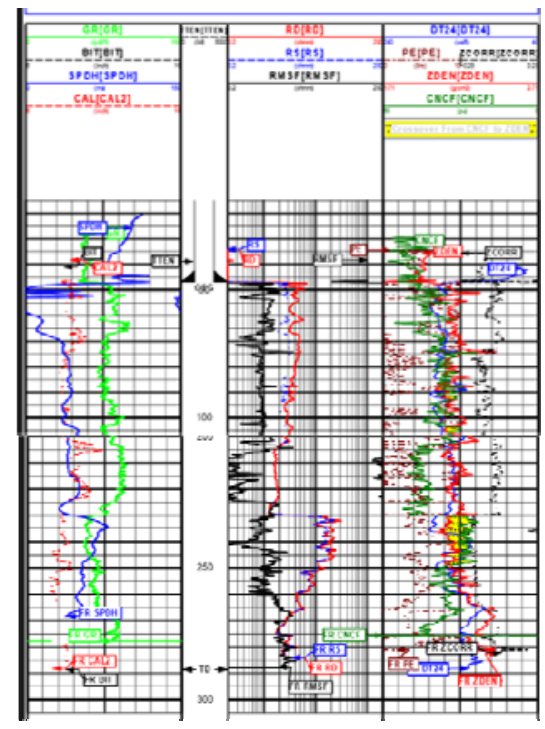

Gambar 2. Log GR Sumur N-9

\section{Data Produksi}

Data produksi yang digunakan dalam perhitungan yaitu perilaku produksi masingmasing sumur

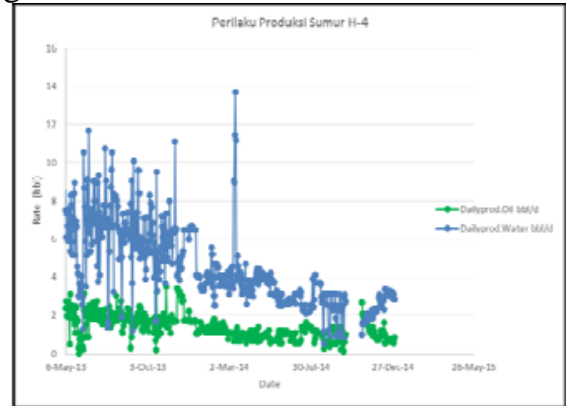

Gambar 3. Perilaku Produksi Sumur H-4

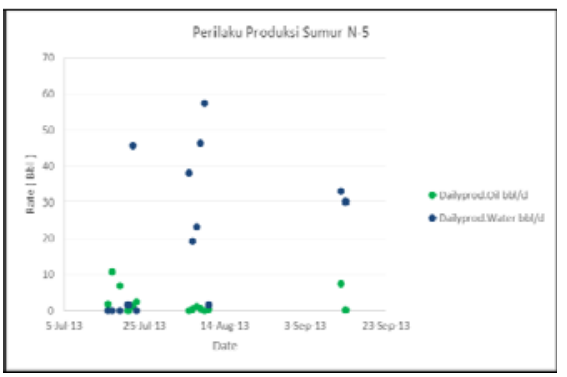

Gambar 4. Perilaku Produksi Sumur N-5

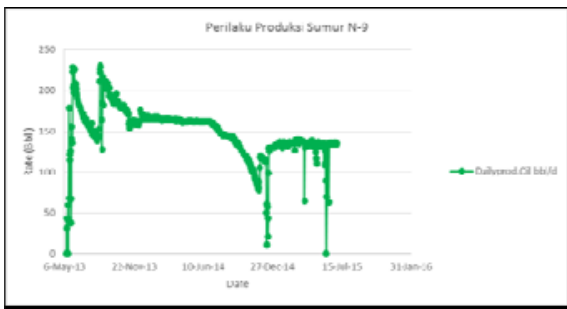

Gambar 5. Produksi Sumur N-9

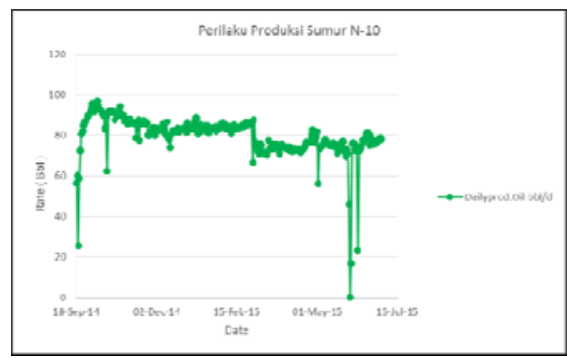

Gambar 6. Produksi Sumur N-10

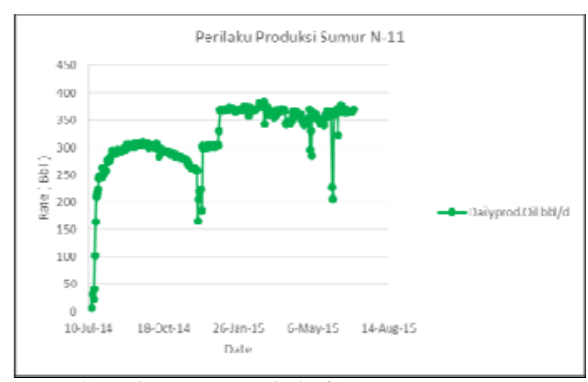

Gambar 7. Produksi Sumur N-11 
Penentuan Sumur Pengembangan Lapangan Minyak Dengan Analisa Petrofisik dan Jari-Jari Pengurasan Studi Kasus : Lapangan Hanania, Lapisan Lima, Formasi Air Benakat Cekungan Sumatra Selatan

\section{Pengolahan Data Property}

1. Penentuan Vshale

Kandungan lempung dalam penelitian ini diperoleh dengan menggunakan indikator kurva tunggal berupa log Gamma Ray (Gambar 4.6). Dari data log GR Sumur N-9, dilakukan perhitungan Vshale dengan menggunakan software petrofisik GS 45 . Persamaan yang digunakan dalam perhitungan $\mathrm{V}_{\text {shale }}$ :

$$
V_{s h}=\frac{G R_{\text {leq }}-G R_{\text {mis }}}{G R_{\text {mak }}-G R_{\text {min }}}
$$

\section{Penentuan Porositas}

Porositas yang menjadi target penelitian adalah nilai porositas efektif atau porositas total yang telah dikurangi oleh faktor kandungan lempung. Porositas total didapat berdasarkan model porositas neutron-densitas. Perhitungan porositas dilakukan dengan menggunakan persamaan :

$$
\Phi_{N D}=\frac{\sqrt{\Phi N^{2}, \Phi D^{2}}}{2}
$$

\section{Penentuan Saturasi Air (Sw)}

Perhitungan nilai saturasi air pada penelitian ini menggunakan persamaan Indonesia dikarenakan persamaan ini dapat membatasi kandungan shale yang mempengaruhi kualitas reservoar.

Perhitungan Saturasi air dilakukan dengan menggunakan persamaan berikut :

$$
\begin{aligned}
& C=\frac{V_{s h}^{\left(1-V_{x x} / 2\right)}}{R_{s h}^{0.5}} \\
& D=\left(\frac{\left(\phi_{t}^{m}\right)^{0.5}}{\left(A \times R_{w f f}\right)^{0.5}}\right) \\
& E=\left(\frac{1}{R_{d}}\right)^{0.5} \\
& S_{w i}=\left(\left(\frac{E}{C+D}\right)^{2}\right)^{1 / n}
\end{aligned}
$$

\section{Penentuan Permeabilitas}

Perhitungan permeabilitas menggunakan persamaan permeabilitas Konzey Carman. Hasil analisis pada salah satu sumur produksi yaitu N-9 (Gambar 8.) terlihat bahwa zona menarik berada pada kedalaman $230 \mathrm{~m}$ (MD) atau pada top Lapisan Lima. Hal ini dikarenakan adanya overlay antara log densitas dengan NPHI kemudian terlihat pula bahwa porositas dan permebilitas yang besar, yang menunjukkan bahwa lapisan tersebut mempunyai kemungkinan dapat dilalui fluida.

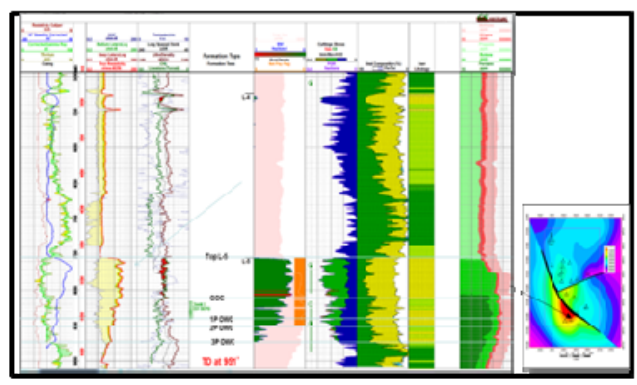

Gambar 8. Salah satu sumur hasil analisis petrofisika (MD) yaitu sumur N-9 yang berada pada Selatan Lapangan Hanania

\section{Penentuan Cutt-off}

\section{Cut-off Porositas dan Vshale}

Membuat grafik antara Porositas vs V-Shale dengan batasan skala yang sudah ditentukan, sebaiknya lapisan/zona yang akan di cut-off memiliki data produksi hidrokarbon. Penentuan cut-off pada lapisan yang memiliki data produksi bertujuan untuk membuat suatu pedoman/patokan (kontrol) besaran nilai cut-off yang menyatakan bahwa dengan batasan porositas minimum, lapisan tersebut menunjukan adanya aliran (flow) hidrokarbon (aliran hidrokarbon dipengaruhi oleh Tekanan, Porositas, Permeabilitas).

Cut-off porositas dan volume shale ditentukan berdasarkan gambar silang kedua harga hasil perhitungan petrofisik reservoir. Pada reservoir minyak, terlihat akumulasi data porositas mengumpul di sebelah kanan (lebih besar dari) harga porositas $19 \%$. Hal itu berarti harga tersebut merupakan cut-off porositas untuk reservoir minyak. Setelah dilakukan cek ulang dengan data tes sumur, terbukti bahwa tes yang menghasilkan hidrokarbon berada di kedalaman dengan porositas dan volume shale yang sesuai dengan batasan harga cut-off tersebut.

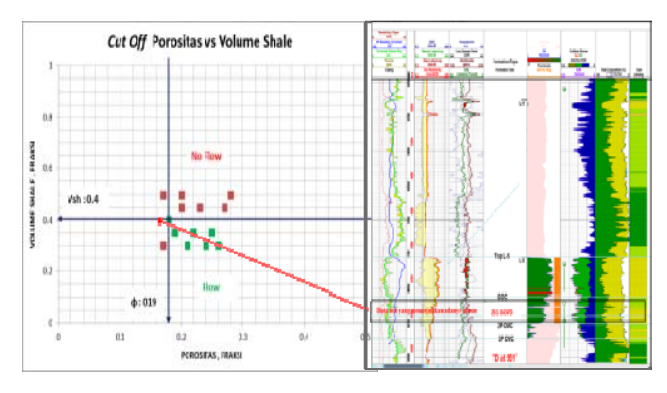

Gambar 9. Cut off Porositas vs Vsh Lapisan Lima

\section{Cut-off Water Saturasi Air}

Cut-off Saturasi Air ditentukan dengan plot antara Water-cut (Wc) dengan Saturasi air, dimana 
kedua data tersebut ditentukan berdasarkan analisa transformasi permeabilitas relatif dari data SCAL dengan harga fraksi aliran air (Wc). Hasil gambar silang Wc dan Sw dari data sumur Lapangan Hanania dapat dilihat pada Gambar 10. Sumbu Y merupakan nilai Wc dan sumbu $\mathrm{X}$ merupakan nilai Sw. Pada gambar tersebut cut-off Sw ditentukan pada nilai Wc 98\%, yakni sebesar 0.7 untuk reservoir minyak.

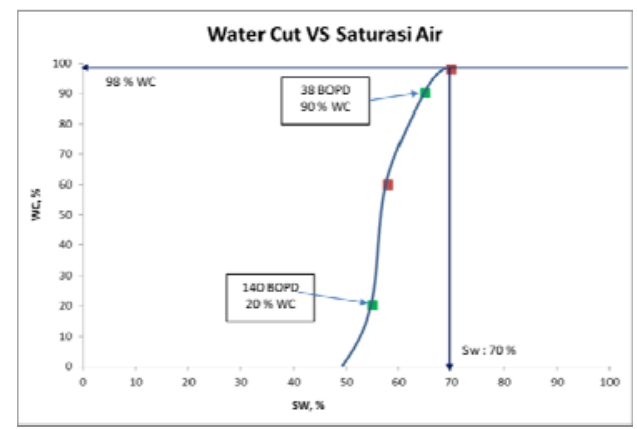

Gambar 10. Cut Off Water Cut vs Saturasi Air Lapisan Lima

Tabel 3. Parameter Petrofisik yang Digunakan dan Hasil Penentuan Cut Off

\begin{tabular}{|c|c|c|c|c|c|c|c|c|c|c|}
\hline \multirow[t]{2}{*}{ Formasi } & \multirow[t]{2}{*}{ J } & \multirow[t]{2}{*}{$\mathrm{m}$} & \multirow{2}{*}{$\mathrm{m}$} & Rw & Rhob & Grmin & Grmaks & Cut Off Por & Cut Off Vsh & cut Off Sv \\
\hline & & & & ohmm & $\mathrm{g} / \mathrm{cm} 3$ & gAPl & $g A P \mid$ & fraksi & fraksi & fraksi \\
\hline Lapisan Lima & 1 & 2 & 2 & 0.73 & 2.21 & 51 & 33 & 0.19 & 0.4 & 0.7 \\
\hline
\end{tabular}

\section{Interpretasi Sumur}

\section{Picking Marker}

Penentuan marker dengan melihat nilai kurva log Gamma Ray. Maximum Flooding Surface (MFS) ditentukan dengan melihat kurva log GR yang paling besar yang menandakan muka air laut mengalami kenaikan paling tinggi. Sedangkan penentuan Sequence Boundary (SB) ditentukan dengan melihat perubahan ketika muka air mengalami penurunan dan kurva log GR terlihat semakin coarsening upward

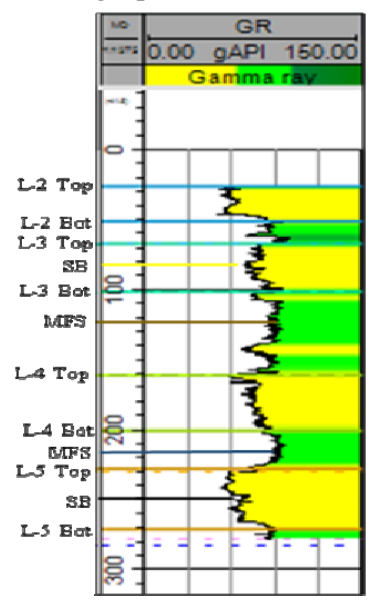

Gambar 11. Litologi Sumur Penelitian N-9

\section{Litologi}

Setelah melakukan picking SB dan MFS, dilakukan penentuan litologi yang bertujuan untuk mengetahui zona yang menarik yang akan digunakan dalam penelitian ini. Penentuan litologi ini digunakan sebagai patokan untuk mengetahui top sand dari masing - masing sumur

\section{Penentuan Fasies dan Lingkungan Pengendapan}

Penentuan lingkungan pengendapan di fokuskan pada Lapisan Lima yang merupakan zona interest dengan ketebalan antara 40 hingga $60 \mathrm{~m}$. Data cutting menyebutkan interval Lapisan Lima disusun oleh batupasir glaukonitan dan jejak calcareous dengan sedikit sisipan serpih, berbutir sangat halus hingga sedang, mikrolaminasi karbonatan, dan sortasi sedang. Dari hasil data cutting ini terlihat bila Lapisan Lima ini memiliki pengaruh fosil lingkungan pengendapan laut. Berdasarkan informasi log, data cutting, dan geologi regional pada formasi Air Benakat Lapisan Lima, lingkungan pengendapan berada pada zona transisi yaitu shallow marine deltaic. Berdasarkan karakter log GR dan data cutting serta analisis penelitian sebelumnya, Lapisan Lima pada penelitian ini termasuk dalam lingkungan pengendapan delta front. Hal ini terlihat dari deskripsi cutting batupasir, yang berbutir sangat halus hingga sedang (Nichols, 2009) dan termasuk dalam endapan Mouthbar serta Interdistributary Channel yang terlihat dari pola log GR.

\section{Interpretasi Seismik}

Berdasarkan laporan penelitian sebelumnya, terdapat 2 patahan yang memotong antiklin pada lapangan Hanania ini, yang pertama berarah NW-SE dan yang kedua berarah W-E keduanya merupakan sesar normal. Sesar pertama merupakan hasil dari aktifitas tektonik muda yang diperkirakan sebagai media migrasi sekunder sampai terjadinya proses pemerangkapan hidrokarbon didalam lapisan batupasir ABF. Sedangkan sesar kedua terletak hampir ditengahtengah struktur dan memiliki vertical displacement sekitar 40 meter dengan sisi Utara sebagai bagian yang turun. Visualisasi dari patahan ini dapat dilihat pada peta struktur Gambar 12. Selain dari laporan penelitian sebelumnya, proses penentuan patahan (fault) juga dilakukan melalui interpretasi pada penampang seismik yang kemudian dikorela sikan dengan korelasi sumur. Dari korelasi sumur sebelumnya terlihat adanya kontras kedalaman antara beberapa sumur yang berdekatan dimana ketika dilihat dari penampang seismik terdapat event patahan. Interpretasi horizon dan patahan dapat dilihat pada Gambar 12. 

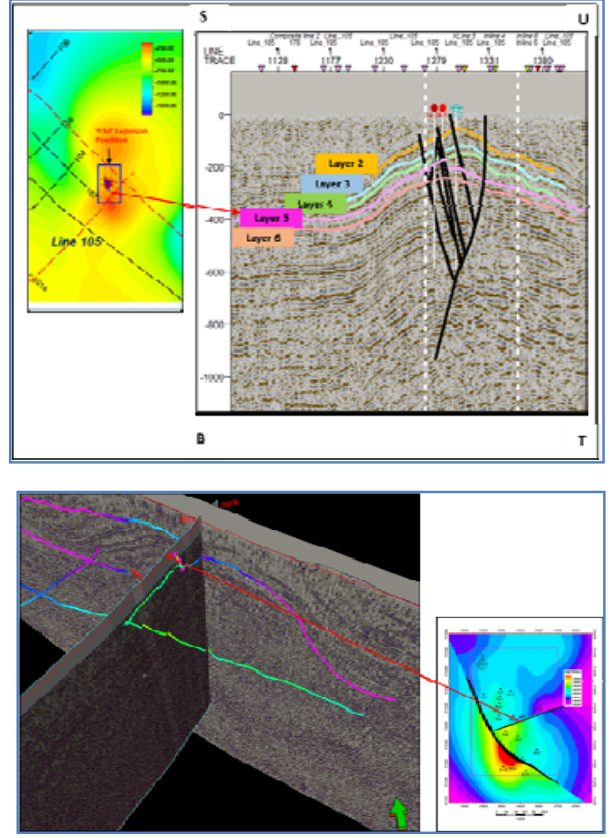

Gambar 12.Interpretasi horizon dan fault pada salah satu seismik 2D line

\section{Peta Struktur}

Pembuatan peta struktur ini dilakukan dengan menggunakan input well top dan horizon yang sebelumnya dijadikan point, kemudian dilakukan interpolasi. Peta struktur yang terbentuk hasil dari interpretasi horizon dan patahan pada awalnya berada pada domain waktu yang kemudian dilakukan konversi time to depth dengan bantuan velocity model menjadi domain kedalaman. Pada Gambar 13. ditampilkan hasil struktur dalam domain kedalaman reservoar L-5 ABF

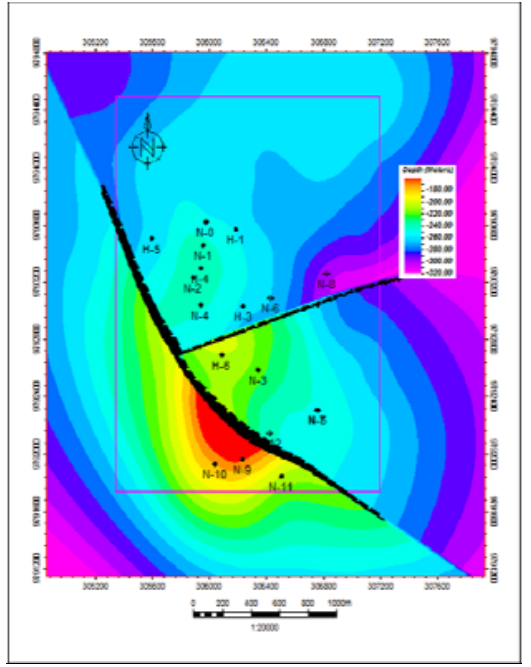

Gambar 13. Peta struktur kedalaman Lapisan Lima (L5) Air Benakat Formasi

\section{Pemodelan Property}

Pada pemodelan property ini, parameterparameter petrofisik dari log dimodelkan. Pemodelan property di Lapangan Hanania meliputi Porositas, Vclay, Permeabilitas, dan Saturasi Air. Distribusi property dari model dilakukan menggunakan pendekatan geostatistik SGS (Sequential Gaussian Simulation).

\section{Scale up Log Data}

Scale up pada dasarnya berupa nilai ratarata property yang diekspansikan ke sekitar daerah sumur. Proses scale up ini menggunakan data property petrofisik yang dimiliki oleh data sumur. Beberapa data well log yang dilakukan scale up antara lain adalah data porositas, permeabilitas, volume shale, dan saturasi air.

Pada proses scale up ini, metode yang digunakan untuk porositas, saturasi air, dan Vclay adalah metode rata-rata aritmetik. Sedangkan untuk permeabilitas digunakan metode geometrik.

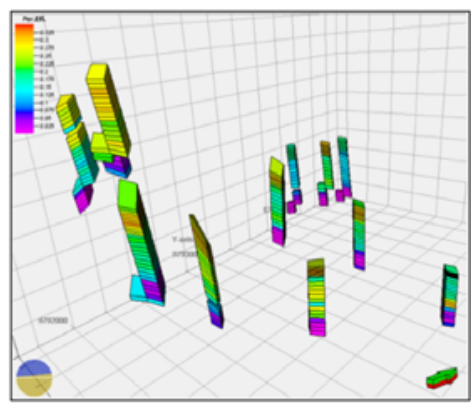

Gambar 14. Hasil scale up data log porositas

\section{Hasil Data}

Hasil data yang didapatkan berupa distribusi dari parameter-parameter petrofisik pada setiap sel dari model. Parameter petrofisik tersebut berupa Porositas, Vclay, Permeabilitas, dan Saturasi Air (Sw).

\section{Porositas}

Arah distribusi pada pemodelan porositas juga berarah yang sama dengan hasil pemodelan dari fasies, yaitu relative Barat Laut - Tenggara.

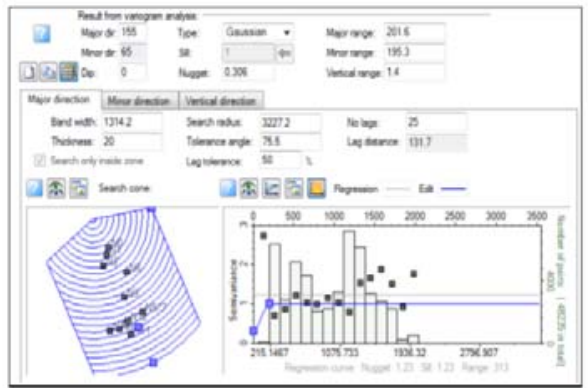

Gambar 15. Hasil variogram pada pemodelan porositas 


\section{Permeabilitas}

Pemodelan permeabilitas menunjukkan persebaran kemampuan batuan meloloskan fluida dimana property ini berhubungan erat dengan porositas batuan. Menggunakan proses perhitungan hubungan permeabilitas dan porositas maka didapatkan log $\mathrm{k}$ (permeabilitas) yang kemudian digunakan untuk disebar dengan metode geostatistik.

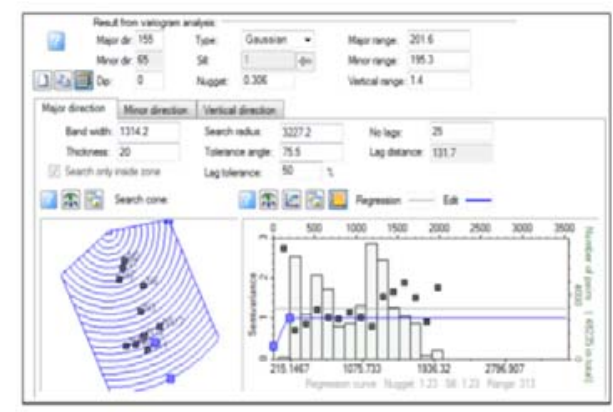

Gambar 16. Hasil variogram pada pemodelan porositas

\section{Volume Shale (Vshale)}

Pemodelan Vshale dilakukan untuk mengetahui peta penyebaran dari batulempung sehingga dapat diketahui penyebaran batupasir. Arah distribusi Vshale juga berarah yang sama dengan hasil pemodelan dari fasies, yaitu relative Barat Laut - Tenggara.

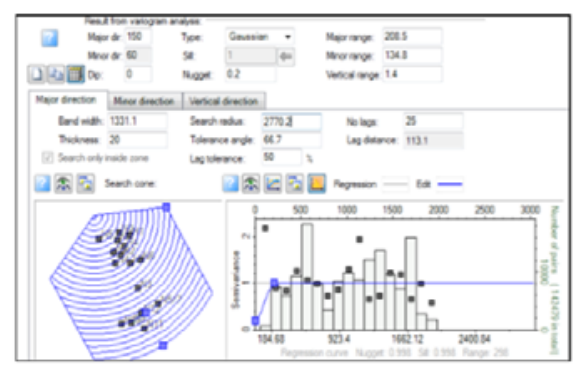

Gambar 16. Hasil variogram pada pemodelan Vshale

\section{Saturasi Air}

Pemodelan Saturasi air dilakukan untuk mengetahui penyebaran air pada suatu batuan. Dengan mengetahui penyebaran saturasi air, maka dapat diketahui dimanakah zona yang dimungkinkan mengandung hidrokarbon. Arah distribusi pada pemodelan saturasi air juga berarah yang sama dengan hasil pemodelan dari fasies, yaitu relatif Barat Laut - Tenggara

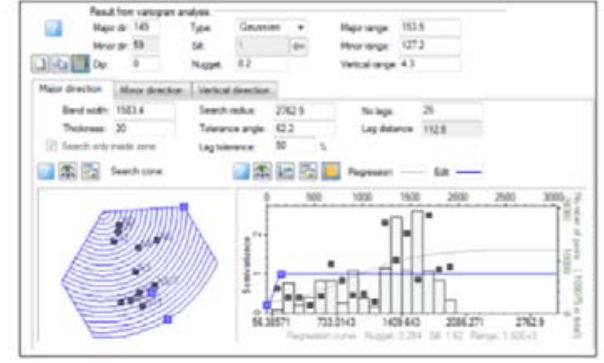

Gambar 16. Hasil Variogram Pada Pemodelan Vshale

\section{Pengolahan Data Produksi}

Data-data produksi dianalisa dan dihitung untuk mendapatkan jari-jari pengurasan sumursumur Lapisan Lima Lapangan Hanania. Hasil perhitungan ini akan dioverlay dengan hasil analisa petrofisik untuk mengetahui arah pengembangan lapangan minyak selanjutnya.

\section{Perhitungan jari-jari pengurasan menggunakan metode volumetric.}

Perhitungan jari-jari pengurasan yang digunakan dalam penelitian ini menggunakan metode volumetric, dimana rumus yang digunakan :

$$
N i=7758 \times V b \times \Phi \frac{(1-S w i)}{B o i}
$$

Tabel 4.

Hasil perhitungan jari-jari pengurasan sumur-sumur Lapisan Lima

\begin{tabular}{|c|c|c|c|c|c|c|c|c|c|}
\hline \multirow{2}{*}{ WELL } & NP & $h$ & $\phi$ & Swi & $B j i$ & $A$ & $A$ & 1 & 1 \\
\hline & BEI & $\mathrm{m}$ & Friksi & Friksi & $B d / S T B$ & Acre & $\pi^{2}$ & ft & $m$ \\
\hline+4 & $545: 00$ & 30.00 & 0.21 & $\cos$ & 120 & $C$. & 118:5.:3 & 62.4 & $18 \pi$ \\
\hline $1-6$ & $\triangle 6400$ & 3000 & 0.21 & $\mathrm{Cu}$ & 120 & C.23 & 100619. & 56.20 & 1728 \\
\hline $\mathrm{N} 2$ & 55.00 & 300 & 0.21 & $\mathrm{CA4}$ & 120 & C.. 3 & 112.15 & 5.9 &. .12 \\
\hline $\mathrm{N4}$ & 543700 & 110 & 0.20 & $\mathrm{css}$ & 120 & C.12 & 526,68 & 4107 & 1252 \\
\hline $\mathrm{N}-5$ & 34.00 & 2201 & 0.25 & C55 & 120 & G. & 4.57 & 3.8 & $: 18$ \\
\hline $\mathrm{N}-\mathrm{G}$ & 248200 & 3.00 & 0.23 & 0.5 & 12 & 150 & 6550.53 & 45.59 & 4.7 \\
\hline II 10 & ;A64:CC & 3200 & 0.22 & $\mathrm{LS4}$ & 120 & (.5) & 21993.65 & $83 ; 0$ & $\mathrm{r}_{45}$ \\
\hline W.11 & 1357900 & 32.00 & 0.22 & [50 & $1 \sqrt{5}$ & 19 & 8 seall.J. & 156.29 & 5052 \\
\hline
\end{tabular}

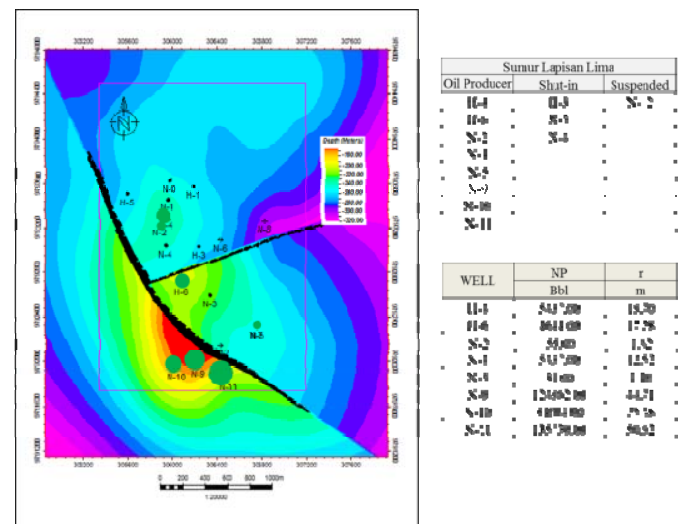

Gambar 17. Jari-jari Pengurasan Lapisan Lima 
Penentuan Sumur Pengembangan Lapangan Minyak Dengan Analisa Petrofisik dan Jari-Jari Pengurasan Studi Kasus : Lapangan Hanania, Lapisan Lima, Formasi Air Benakat Cekungan Sumatra Selatan

\section{Hasil dan Pembahasan}

\section{Analisa Hasil Pemodelan Property Petrofisik Lapisan Lima Terhadap Pengembangan Lapangan Hanania}

Pemodelan property petrofisika yaitu permeabilitas, porositas efektif, Vshale, yang digunakan sebagai property untuk mengetahui pola penyebaran hidrokarbon pada lapangan Hanania.

Pemodelan Vshale dilakukan untuk mengetahui pola penyebaran batulempung dimana tujuan akhirnya adalah untuk mengetahui persebaran batupasir. Nilai Vshale yang besar menunjukkan akumulasi batulempung yang besar sedangkan Vshale yang kecil menunjukkan akumulasi batulempung yang kecil yang mengidentifikasikan adanya batupasir. Setelah didapat hasil pemodelan Vshale dilakukan perhitungan untuk mendapatkan nilai Net Sand.

Gambar 18. adalah peta net sand Lapisan Lima. Bagian Selatan-Barat-Utara mempunyai net sand yang cukup tebal berkisar 30 - 34 meter dibandingkan bagian Timur. Hal ini menunjukkan arah Selatan-Barat-Utara mempunyai potensi hidrokarbon yang baik.

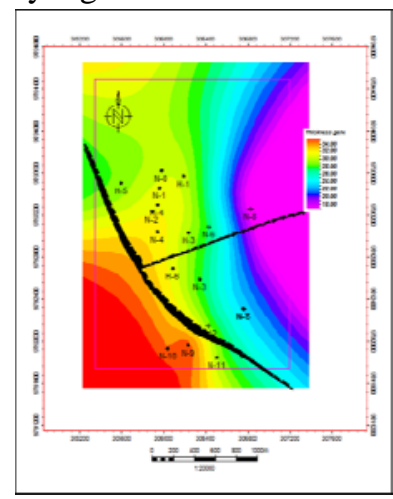

Gambar 18. Peta Net Sand Lapisan Lima (L-5)

Gambar 19 adalah peta net pay Lapisan Lima. Bagian Selatan mempunyai net pay yang cukup tebal berkisar 30 - 34 meter dibandingkan bagian lainnya. Hal ini menunjukkan arah Selatan mempunyai potensi hidrokarbon yang baik.

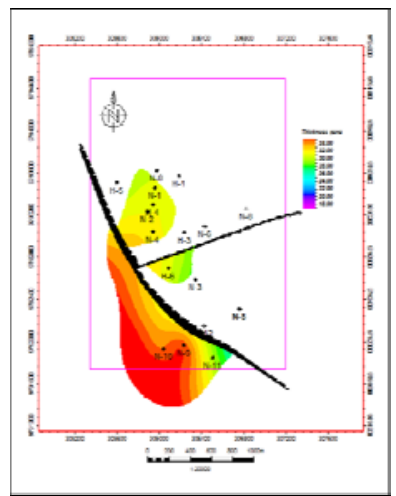

Gambar 19. Peta Net Pay Lapisan Lima (L-5)
Pada gambar 20. adalah peta porositas. Bagian Selatan, Barat dan Utara mempunyai nilai porositas berkisar 21-25\%, lebih tinggi dibandingkan nilai porositas bagian Timur. Hal ini menunjukkan batuan arah Selatan, Barat dan Utara mempunyai nilai porositas yang tinggi sehingga memungkinkan adanya fluida.

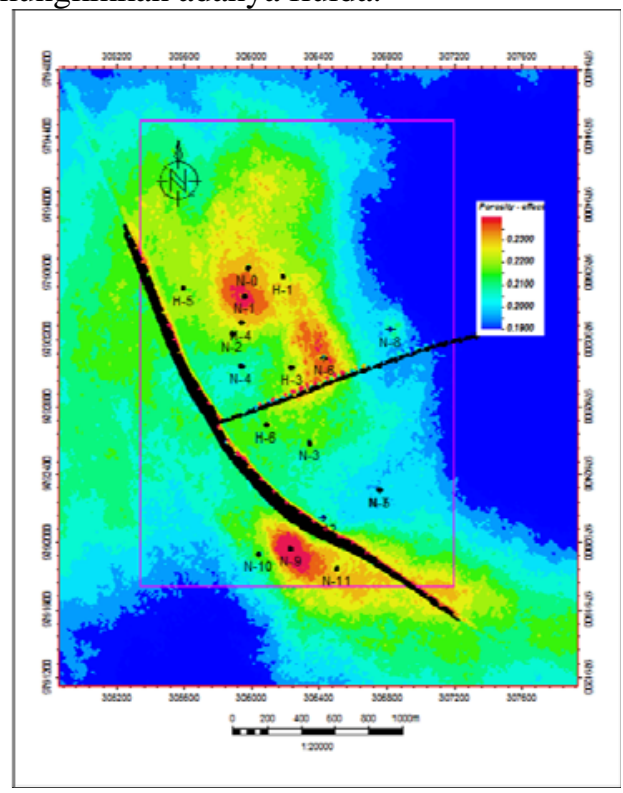

Gambar 20. Peta Porositas Lapisan Lima (L-5)

Pada gambar 21. terlihat adanya nilai permeabilitas yang cukup tinggi di bagian Selatan berkisar 20 - $80 \mathrm{mD}$ dibandingkan bagian Utara Timur. Hal ini menunjukkan kemampuan batuan mengalirkan fluida pada bagian Selatan cukup baik.

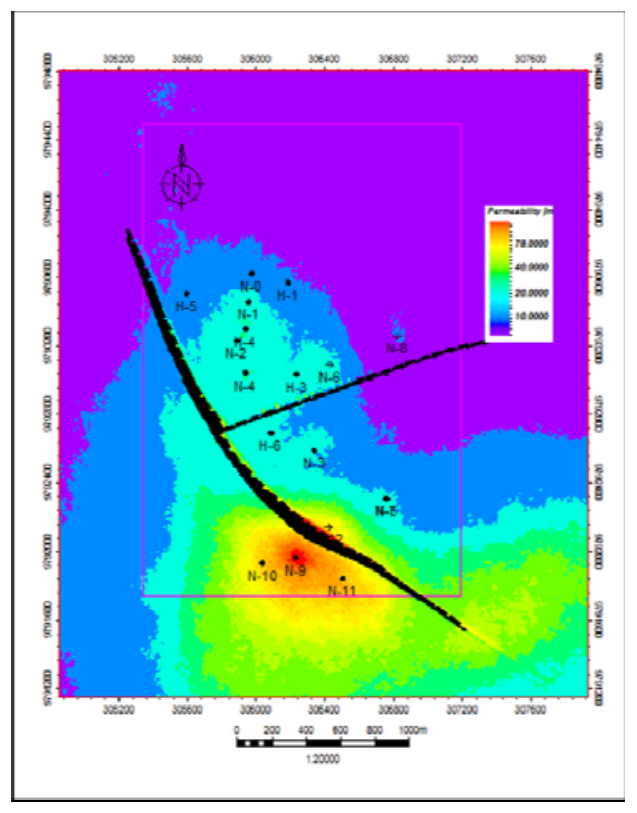

Gambar 21. Peta Permeabilitas Lapisan Lima 
Pemodelan Saturasi Air dilakukan untuk mengetahui penyebaran air pada batuan. Dengan mengetahui penyebaran Sw ini dapat diketahui dimanakan daerah yang mungkin mengandung hidrokarbon. Semakin tinggi nilai $\mathrm{Sw}$ maka semakin tinggi kandungan air pada batuan tersebut sedangkan semakin rendah nilai Sw maka semakin tinggi kemungkinan terkandungnya hidrokarbon.

Pada gambar 22. terlihat nilai saturasi air yang rendah di bagian Selatan berkisar 0.7-0.9 dibandingkan bagian Barat-Utara-Timur. Hal ini menunjukkan kemungkinan terkandungnya hidrokarbon pada bagian Selatan cukup tinggi.

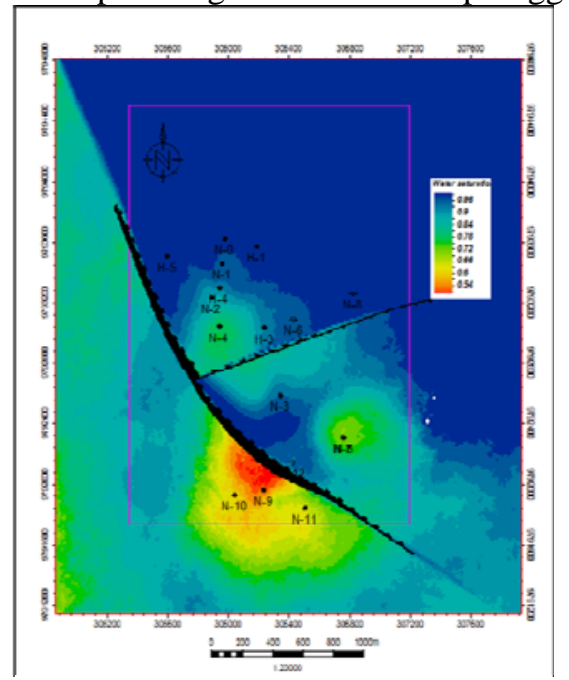

Gambar 22. Peta Saturasi Air Lapisan Lima (L-5)

Untuk formasi Air Benakat pada Lapisan Lima yang merupakan zona penghasil hidrokarbon, terlihat adanya kesesuaian property yang saling mendukung antara satu property dengan property lainnya, dengan kondisi permeabilitas, porositas, net sand yang baik serta saturasi air yang rendah, menujukkan bahwa zona tersebut merupakan zona yang menarik.

Berdasarkan hasil analisa pemodelan property, zona yang memungkinkan untuk dilakukan proposed new well berada pada Selatan - Barat Daya - Tenggra lapangan Hanania. Untuk membuktikannya dilakukan analisa bubble map terhadap sumur-sumur yang berproduksi pada Lapisan Lima lapangan Hanania.

\section{Analisa Hasil Overlay Property Petrofisik dengan Jari-jari Pengurasan}

Jari-jari pengurasan sumur-sumur produksi Lapisan Lima dihitung menggunakan metode volumetric. Hasil perhitungannya akan di overlay dengan hasil property petrofisik yang telah dilakukan untuk menentukan arah pengembangan lapangan . Gambar 23. merupakan peta net sand overlay dengan jari-jari pengurasan pada sumursumur Lapisan Lima. Terlihat pada bagian Selatan yang mempunyai net sand tebal, komulatif produksi sumur-sumur di bagian tersebut cukup besar dengan jari-jari pengurasan berkisar 25 - 50 m (N-10, N-9, N-11).

Pada bagian Barat dan Utara mempunyai net sand tebal tetapi komulatif produksi sumur $\mathrm{N}$ 4, H-1 dan H-4 kecil dengan jari-jari pengurasan berkisar 1-18 meter . Untuk itu dilakukan overlay dengan property reservoar (porositas dan permeabilitas).

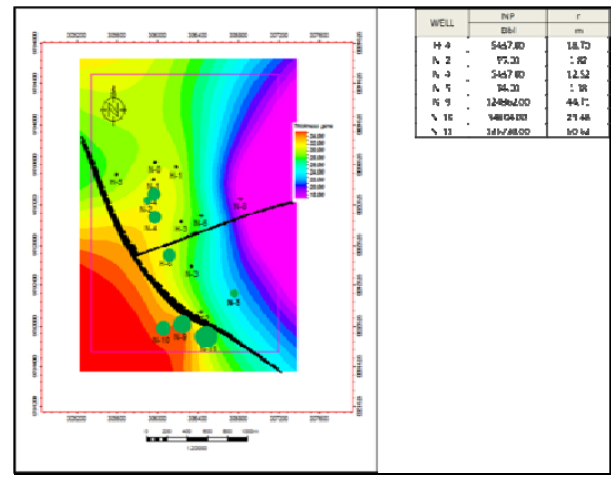

Gambar 23. Overlay Net Sand dengan Jari-jari Pengurasan Lapisan Lima (L-5)

Gambar 24. merupakan peta net pay overlay dengan jari-jari pengurasan pada sumursumur Lapisan Lima. Terlihat pada bagian Selatan yang mempunyai net pay tebal, komulatif produksi sumur-sumur di bagian tersebut cukup besar dengan jari-jari pengurasan berkisar 25 - 50 m (N-10, N-9, N-11). Pada bagian Barat dan Utara mempunyai net pay kecil, komulatif produksi sumur N-4, H-1 dan H-4 juga kecil dengan jari-jari pengurasan berkisar 1-18 meter .

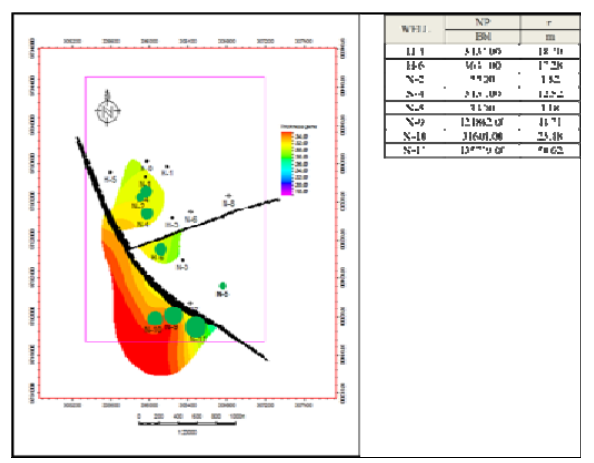

Gambar 24. Overlay Net Pay dengan Jari-jari Pengurasan Lapisan Lima (L-5)

Gambar 25. merupakan gambar peta porositas overlay dengan jari-jari pengurasan. Pada bagian Selatan, nilai porositasnya cukup tinggi, berkisar 23-25\% dibandingkan bagian Barat, Utara 
Penentuan Sumur Pengembangan Lapangan Minyak Dengan Analisa Petrofisik dan Jari-Jari Pengurasan Studi Kasus : Lapangan Hanania, Lapisan Lima, Formasi Air Benakat Cekungan Sumatra Selatan

dan Timur. Hal ini menunjukkan, pada bagian Selatan dengan net sand yang tebal dan porositas yang tinggi menghasilkan komulatif produksi yang besar. Bagian Utara walaupun net sandnya tebal, nilai porositasnya kecil sehingga komulatif produksi yang dihasilkan juga kecil. Untuk lebih memperkuat hasil analisa, dilakukan overlay permeabilitas dengan jari-jari pengurasan.

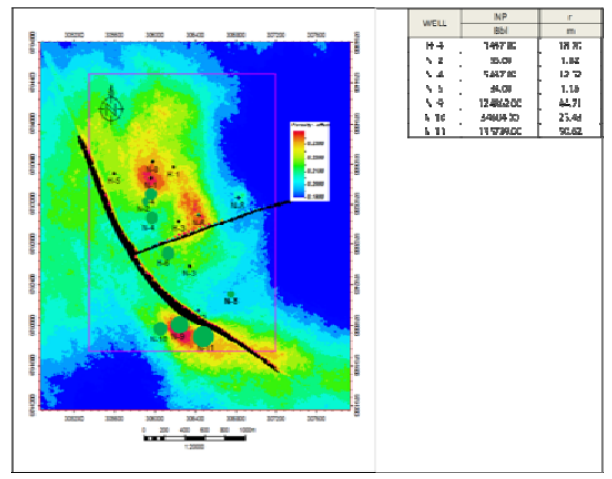

Gambar 25. Overlay Porositas dengan Jari-jari Pengurasan Lapisan Lima (L-5)

Gambar 25. merupakan overlay permeabilitas dengan jari-jari pengurasan. Terlihat pada bagian Selatan permeabilitas cukup besar berkisar 20 - $80 \mathrm{mD}$. Hal ini menunjukkan, pada bagian Selatan dengan net sand dan net pay yang tebal, porositas dan permeabilitas yang tinggi menghasilkan komulatif produksi yang besar. Bagian Barat walaupun permeabilitasnya tinggi, net sandnya tebal, nilai porositasnya lebih kecil sehingga komulatif produksi yang dihasilkan juga kecil. Untuk lebih memperkuat hasil analisa, dilakukan overlay saturasi air dengan jari-jari pengurasan.

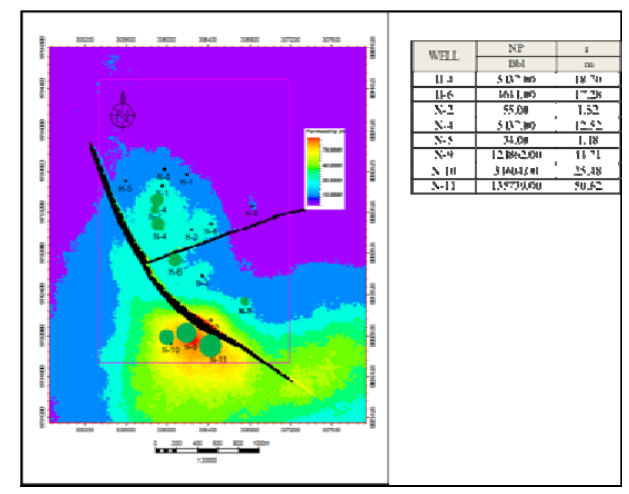

Gambar 26. Overlay Permeabilitas dengan Jari-jari Pengurasan Lapisan Lima (L-5)

Gambar 26. merupakan overlay saturasi air dengan jari-jari pengurasan. Terlihat pada bagian Selatan nilai saturasi airnya lebih rendah dibandingkan bagian Utara, Barat dan Timur. Hal ini menunjukkan, pada bagian Selatan dengan net sand dan net pay yang tebal, porositas dan permeabilitas yang tinggi serta saturasi air yang rendah menghasilkan komulatif produksi yang besar.

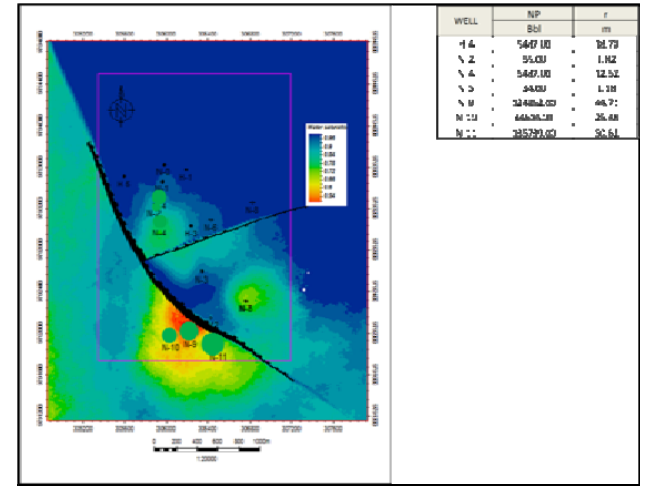

Gambar 25. Overlay Saturasi Air dengan Jari-jari Pengurasan Lapisan Lima (L-5)

\section{Skenario Penentuan Sumur-sumur baru Lapisan Lima (L-5)}

Acuan yang digunakan dalam penentuan sumur baru diantaranya :

- Sumur baru terletak di daerah tinggian

- Letak sumur yang dijadikan acuan (referensi) dengan sumur baru minimal 500 meter

- Cross section antar sumur

- Produksi minyak dari sumur yang dijadikan acuan (referensi) besar.

Berikut beberapa skenario yang dibuat berdasarkan analisa petrofisik dan jari-jari pengurasan diatas.

\section{Skenario 1}

\section{Penentuan Sumur-sumur baru di bagian} Selatan - Tenggara

Berdasarkan hasil analisa petrofisik, bagian Selatan - Tenggara mempunyai nilai petrofisik yang baik. Selain itu, terdapat sumur yang mempunyai produksi besar (N-11) dengan komulatif produksi 135 Mbbl yang dapat dijadikan referensi dalam menentukan pengembangan sumur-sumur baru. Berikut sumur-sumur baru yang diajukan pada bagian Selatan - Tenggara (Tabel 5) dan Gambar 26 :

Tabel 5.Skenario 1

Sumur-sumur Pengembangan Lapisan Lima (L-5)

\begin{tabular}{|c|c|c|c|c|c|c|}
\hline \multirow{2}{*}{ Surnur Baru } & \multicolumn{2}{|c|}{ Koordinat } & \multirow{2}{*}{$\begin{array}{c}\text { Porositas } \\
\text { traksi }\end{array}$} & \multirow{2}{*}{\multicolumn{2}{|c|}{\begin{tabular}{|cc} 
Permeabilitas & Saturasi Air \\
$\mathrm{mD}$ & traksi \\
\end{tabular}}} & \multirow{2}{*}{ Ranekin } \\
\hline & $\mathrm{x}(\mathrm{m})$ & $\mathrm{Y}(\mathrm{m})$ & & & & \\
\hline A & $3 \sin$ & 90:350 & 02 & $\mathbf{a}$ & 19 & 1 \\
\hline B & IISII & Strom & 02 & $\bar{m}$ & 106 & 2 \\
\hline C & 301001 & 9rosen & a.1 & $\pi$ & 10 & 3 \\
\hline 0 & 306s: & 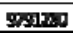 & בם & $\pi$ & a & 4 \\
\hline $\mathbf{E}$ & 3092 & 95:150 & ax & $\pi$ & $a n$ & S \\
\hline
\end{tabular}




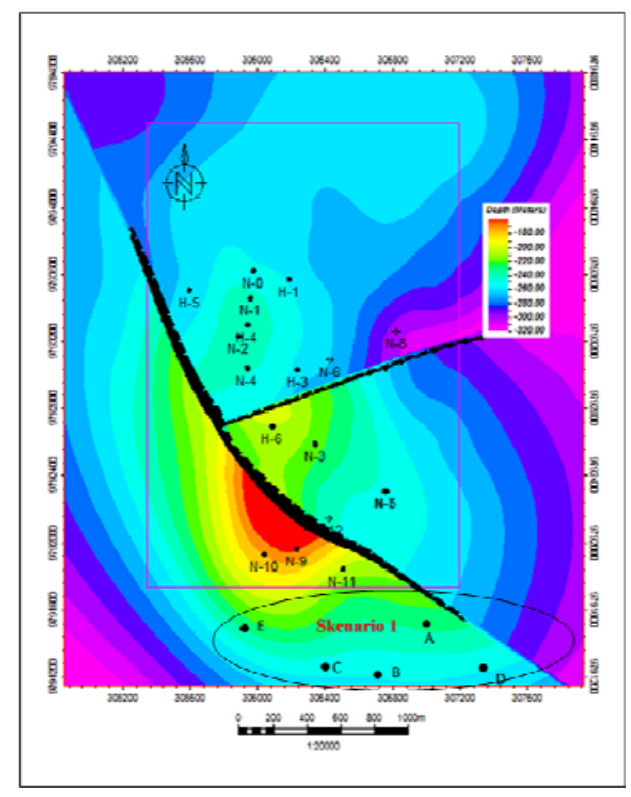

Gambar 27. Sumur Pengembangan Lapisan Lima Bagian Selatan - Utara

\section{Skenario 2}

Penentuan Sumur-sumur baru di bagian Selatan - Barat Daya

Berdasarkan hasil analisa petrofisik, bagian Selatan - Barat Daya mempunyai nilai petrofisik cukup bagus dan terdapat sumur yang mempunyai produksi besar (N-10) dengan komulatif produksi $34 \mathrm{Mbbl}$ yang dapat dijadikan referensi dalam menentukan pengembangan sumur-sumur baru. Berikut sumur-sumur baru yang diajukan pada bagian Selatan - Barat Daya (Tabel 6) dan Gambar 26 :

Tabel 6. Skenario 2

Sumur-sumur Pengembangan Lapisan Lima (L-5)

\begin{tabular}{|c|c|c|c|c|c|c|}
\hline \multirow{2}{*}{ Sumur Baru } & \multicolumn{2}{|c|}{ Koordinat } & Porositas & Permeabilitas & Saturasi Air & \multirow{2}{*}{ Rangking } \\
\cline { 2 - 6 } & $\mathrm{X}(\mathrm{m})$ & $\mathrm{Y}(\mathrm{m})$ & fraksi & $\mathrm{mD}$ & fraksi & \\
\hline F & 305720 & 9791200 & 0.21 & 65 & 0.75 & 6 \\
\hline G & 305680 & 9792560 & 0.21 & 64 & 0.77 & 7 \\
\hline H & 305520 & 9792800 & 0.21 & 62 & 0.78 & 8 \\
\hline I & 305360 & 9792440 & 0.20 & 60 & 0.80 & 9 \\
\hline J & 305600 & 9792240 & 0.20 & 57 & 0.80 & 10 \\
\hline K & 305520 & 9791840 & 0.20 & 54 & 0.82 & 11 \\
\hline L & 305080 & 9792000 & 0.19 & 50 & 0.83 & 12 \\
\hline M & 305160 & 9791520 & 0.19 & 47 & 0.84 & 13 \\
\hline N & 305080 & 9793200 & 0.19 & 45 & 0.85 & 14 \\
\hline O & 305080 & 9793280 & 0.19 & 40 & 0.85 & 15 \\
\hline
\end{tabular}

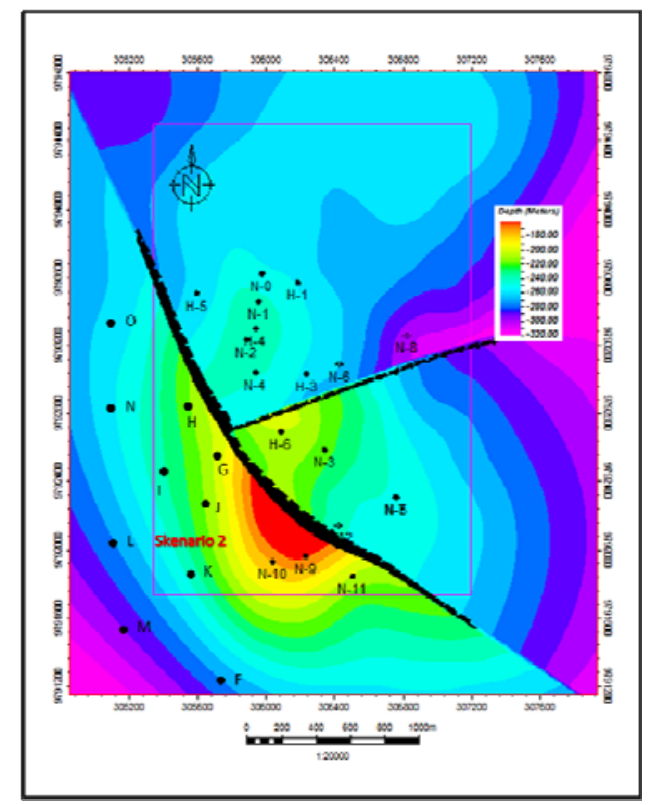

Gambar 26. Sumur Pengembangan Lapisan Lima Bagian Selatan - Barat Daya

\section{Kesimpulan}

1. Delta Front dengan interpretasi fasiesnya adalah MouthBar dan Interdistributary Channel.

2. Berdasarkan perhitungan dan analisis petrofisika dari pemodelan property diperoleh cut - off hidrokarbon Lapisan Lima adalah porositas 0.19 fraksi dan saturasi air 0.7 fraksi.

3. Berdasarkan perhitungan petrofisik, bagian Selatan Lapisan Lima lapangan Hanania mempunyai kisaran nilai net sand 30 - 34 $\mathrm{m}$, porositas $0.22-0.25$ fraksi, permeabilitas $20-80 \mathrm{mD}$ dan saturasi air $0.7-0.9$ fraksi.

4. Berdasarakan perhitungan jari-jari pengurasan, sumur-sumur produksi bagian Selatan mempunyai kisaran jari-jari pengurasan 25 - $50 \mathrm{~m}$ dengan kisaran kumulatif produksi 34 - $135 \mathrm{Mbbl}$.

5. Berdasarkan hasil analisa overlay property petrofisik dengan jari-jari pengurasan, bagian Selatan mempunyai nilai property petrofisik yang bagus dengan produksi kumulatif yang besar.

6. Lokasi sumur baru yang dapat direkomendasikan berdasarkan WKP yaitu pada bagian Selatan - Barat Daya dengan koordinat sebagai berikut :

\begin{tabular}{|c|c|c|c|c|c|c|}
\hline \multirow{2}{*}{ Sumur Buru } & \multicolumn{2}{|c|}{ Koordinat } & \multirow{2}{*}{$\begin{array}{c}\text { Porositas } \\
\text { rraksi }\end{array}$} & \multirow{2}{*}{\begin{tabular}{|c|} 
Permcabilitas \\
$m D$
\end{tabular}} & \multirow{2}{*}{$\begin{array}{c}\text { Saturasi Air } \\
\text { fraksi }\end{array}$} & \multirow{2}{*}{ Ranngking } \\
\hline & $x(\mathrm{~m})$ & $Y(\mathrm{mr})$ & & & & \\
\hline 5 & 5300 & SWEN & 021 & $\bar{a}$ & 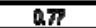 & 1 \\
\hline H & X550 & genand & 0.71 & a & D.7B & 2 \\
\hline $\mathrm{T}$ & conser & shenen & 0.20 & 急 & and & 3 \\
\hline J & [n: & 8 singo & 65 & $\bar{g}$ & D要 & 4 \\
\hline I & $2050 x$ & Shaten & 0.20 & 54 & 29 & 5 \\
\hline
\end{tabular}


Penentuan Sumur Pengembangan Lapangan Minyak Dengan Analisa Petrofisik dan Jari-Jari Pengurasan Studi Kasus : Lapangan Hanania, Lapisan Lima, Formasi Air Benakat Cekungan Sumatra Selatan

\section{Daftar Pustaka}

Ahmad Syahri Fadhli Haqqi, Edy Sunardi, Vijaya Isnaniawardhani, Analisis Fasies dan Sikuen Stratigrafi Formasi Air Benakat Berdasarkan Data Well Log, Pada Lapangan "EA" Cekungan Sumatra Selatan, Fakultas Teknik Geologi Universitas Padjajaran

Bishop, M. G. 2001. South Sumatra Basin Province, Indonesia: The Lahat/Talang Akar - Cenozoic Total Petroleum System. USGS.

Bohlig, Geoff. 2005. Kriging. Oktober.

Boggs, Sam. 2009.Petrology of Sedimentary Rocks. Second Edition. Cambridge University Press.

Dadang Rukmana, Dedy Kristanto, V. Dedi Cahyoko Aji. 2011 Teknik Reservoir Teori dan Aplikasi.

Dadang Rukmana..2014. Technical Aspect Subsurface,

George P Allen and Francis Mercier. 1994 Resevoir facies and Geometry ini mixed tide and fluvial-dominated delta mouth bars : example from the modern Mahakam delta (east Kalimantan). IPA,2006 - 23rd Annual Convention Proceedings. Oktober..

Ginger, D. The Petroleum Systems and Future Potential of The South Sumatra Basin.

Harsono, A. 1997. Evaluasi Formasi dan Aplikasi Log. Schlumberger Oilfield Services.

Kendall, C. G. Sequence Stratigraphy. University of South California. 2005

Muhammad Imam Pratama, Edy Sunardi, Nurdrajat, Sikuen Stratigrafi Fasies

Pengendapan dan Zonasi Hidrokarbon pada Lapangan "VN" pada Cekungan Sumatra Selatan, Fakultas Teknik Geologi Universitas Padjajaran

Neal, Jack, David Risch and Peter Vail. 1993. Oilfield Review. Sequence Stratigraphy-A Global Theory for Local Success.

Nichols, G. 1999 .Sedimentology and Stratigraphy. Blackwell Publishing.

NN.Internal Report of PBMSJ

Schlumberger. 2010. Property Modeling Course.Petrel Handbook..
Schlumberger, 2004, Petrel Workflow Tools: Property Modeling, Schlumberger Innovation Solutions

Solution, S. E. 2011. Histograms and SGS Modeling.

Sukmono, Sigit. 2007. Fundamental of Seismic Interpretation. Volume 1. Dept. of Geophysical Engineering, ITB.

Sukmono, Sigit. 2007. Fundamental of Seismic Interpretation. Volume 2. Dept. of Geophysical Engineering, ITB.

TAC-PT.PERTAMINA 2011, Plan Of Development (POD) Lapangan Betung dan

Lapangan Meruo Senami Jambi

Walker, N. P. 1992. Facies Model Response to Sea Level Changes. Geological Association of Canada.

Walker, R. G. Facies Models, Second Edition. The Geological Association Canada. 1984. 